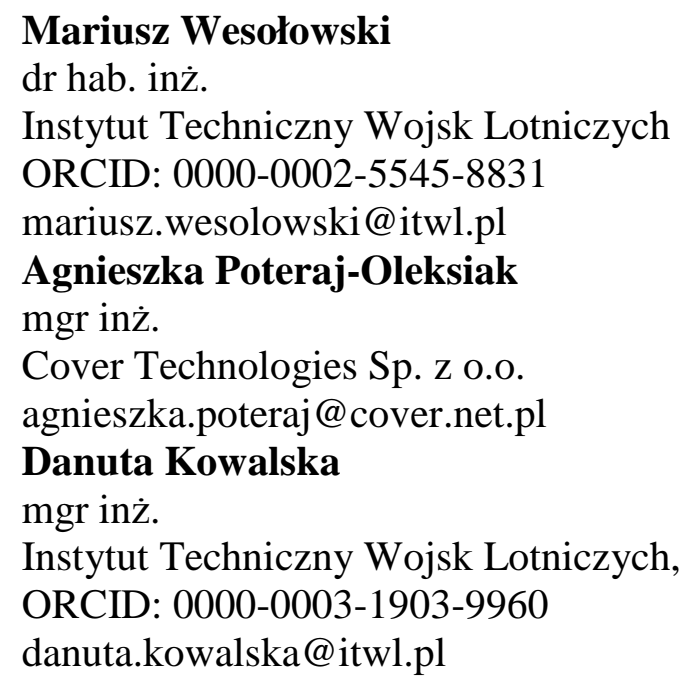

DOI: 10.35117/A_ENG_21_09_10_11_07

\title{
Stabilization of the subsoil and leveling of concrete paving slabs
}

\begin{abstract}
In the process of using airport pavements, destructive processes of concrete slabs caused by operational loads and environmental factors are observed. One of the most common damages to concrete surfaces is thresholds (faults) - vertical displacements of the edges of the slabs or displacements on the cracks of the slabs, resulting from damage to the subsoil or foundation. Performing periodic inspections of the technical condition of the pavement allows you to monitor the changes taking place and at the same time plan repairs, which is associated with the selection of appropriate materials for their implementation. This article is devoted to the issue of stabilization and leveling of concrete pavement slabs in the low-pressure injection technology with the use of specialized injection materials (resins). The technology of board re-leveling is used in places of settlement, permanently strengthening the subsoil or substructure, as well as allowing to restore the required parameters of surface evenness. The article presents the results of laboratory tests as well as the results of field tests carried out before and after the injection works, based on the example of works carried out at one of the airport facilities in Poland. The article presents, among others the results of the load-bearing and evenness tests of the pavement and the results of the tests with the use of GPR. The presented technology belongs to non-invasive repair solutions and short-term works.
\end{abstract}

Keywords: concrete pavement; Geotechnical injections; Keystroke plates

\section{Introduction}

Properly constructed and operated airfield pavement made of cement concrete must ensure the safety of air operations. Due to the large take-off weight of modern aircraft, which travel at high speeds during take-off and landing, a surface with an assumed load-bearing capacity, adequate evenness, and roughness is required. In the process of pavement use, destructive processes occur due to operational loads and environmental factors. Any damage to the surface must be repaired. It is extremely important that the performance of maintenance works does not stop air operations for a longer period of time. One of the methods that allows restoring the required parameters of the pavement can be the low-pressure injection technology. 


\section{Damage to concrete surfaces}

Concrete pavements are extremely practical and economical, provided that we know how to handle them during operation and how to eliminate the causes of any damage. Generally, we divide damage into two types: structural and superficial. Structural damage, which is evidence of the durability of the pavement structure, primarily cracks in the boards originating on the surface or in the bottom of the layers, deformation of the joints, subsidence (keying) of the boards $[5,6,7]$. Surface damage, i.e. the durability of the driving layer, is abrasion of the surface, surface flaking (shallow and deep), hairline and mesh cracks, frost cracks, and edge damage to the boards. On the other hand, point damage consists of craters (small air voids), orange chippings, deep cavities, and broken corners of concrete slabs [4, 8]. For example, plate edge fracture as a result of subsidence is shown in Figure $\mathbf{1 .}$

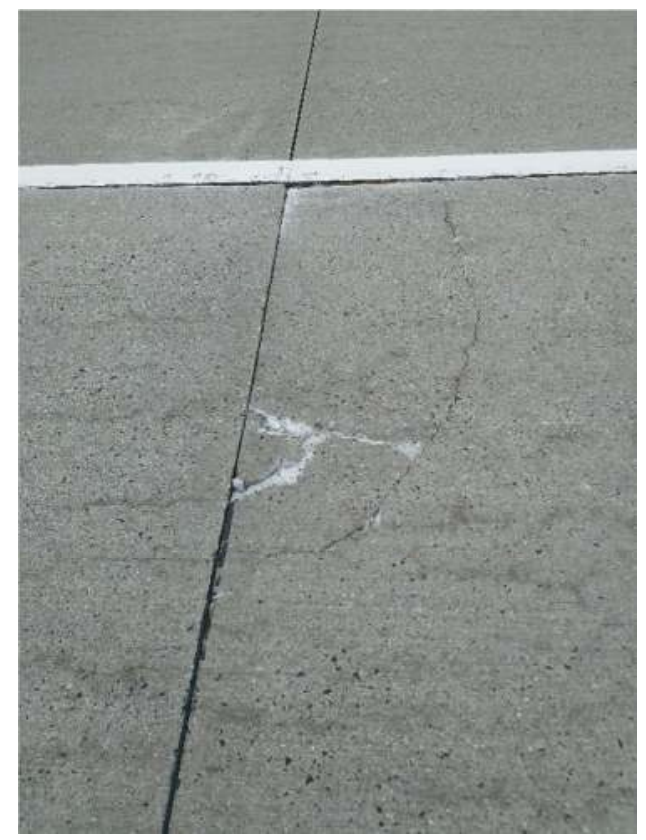

1. Plate edge breakage as a result of subsidence

The durability of the pavement structure depends on its structural damage resulting from the impact of vehicle traffic on it. This causes cyclical stresses and tensile strains in the pavement, causing fatigue cracks over a long period of operation. The number of loads transferred by the pavement is defined as the fatigue life. The structure of the pavement (layer thickness) and the quality (mechanical parameters) of the materials determine the fatigue life [7].

The strategy of maintaining the condition of the pavement of a given type must take into account surface maintenance treatments performed with appropriate frequency so that the pavement does not suffer excessive damage, which may result in a significant reduction of its structural durability. It should be added that there are no surfaces that do not require maintenance. The durability of the pavement should in fact be understood as a set of various features that determine the lifetime of the pavement (road) and the costs of its maintenance [7].

\section{Settlement of concrete slabs}

The settlement of concrete slabs is one of the most common phenomena during the use of traffic pavements. It is caused by the lack of cooperation between the plates, the lack of sufficient support, which in turn leads to uneven lowering of the plates under heavy load [1]. 
Lack of sufficient support of the paving slabs may be caused by problems in the substructure. Reasons such as loosening of the framework material due to water penetration, and washing away of the material lead to its weakening. There may be voids under the slab, the so-called caverns that significantly reduce the load-bearing capacity of the structure.

The phenomenon of settling plates should be eliminated immediately after identifying the causes [7]. Otherwise, the weakened structure will be subject to further rapid degradation manifested in the form of plate cracks, edge fractures, etc.

In the case of airports, the displacement of the edges of the plates up to $1 \mathrm{~cm}$ is not a factor that eliminates the surface from air traffic but limits its use. The formation of thresholds between the edges of adjacent paving slabs causes many difficulties in exploitation, such as pools of water, ice-covered surfaces in winter, deformation of the grade line, and their further consequences $[5,8]$. The occurrence of thresholds between the edges of individual plates is associated with the deterioration of the evenness [2], may affect the load capacity of the structure [3], which may have negative consequences for the aircraft moving on them.

\section{Geotechnical injections}

In the field of structural repairs, an effective and proven solution are geotechnical injections, ie a non-burdensome and non-invasive technology of strengthening and stabilizing the subsoil and structures [1,9]. This prevents, among others. landslides, which may result in breakdowns or construction disasters. Soil stabilization is used mainly in hard-to-reach places, where mobilization of heavy equipment is impossible due to technical reasons and economic constraints. Injection successfully replaces jet grouting technology in these types of situations. It is indispensable for the issue of deep foundations, micro tunneling, and strengthening of slopes and excavations.

A geotechnical injection is a process by which pumpable material is remotely injected into the ground. It is indirectly controlled by the selection of the rheological properties of the injection and the injection parameters, i.e. pressure, volume, expenditure. There are two types of geotechnical injection [10]. The first is a non-displacement filling injection, replacing water or pore space in the soil with an injection or mortar, without clear soil displacement. The term includes penetrant injection and volumetric filling. The second type is a displacement (push) injection - injection of the substrate in such a way that it causes deformation, compression, or displacement of the soil [10].

The production technology applies to the injection process that stabilizes dry and moist soil as well as filling cavities, caverns, and voids in the soil structure. The scope of use depends on the temperature and is within the range: $+3{ }^{\circ} \mathrm{C}-+30^{\circ} \mathrm{C}$ for resin-based materials.

The use of intelligent, two-component, fast-acting materials based on resins eliminates the need to demolish the building, injection works are performed in a non-invasive way, consisting in drilling perpendicular holes with a diameter of no more than $14 \mathrm{~mm}$ through the surface plates (Figure 2). Accurate selection of the parameters of the injection should be preceded by tests and in some cases a trial section in order to identify the situation and clarify the parameters of the injection material in terms of foamability (foamable - expansive, nonfoaming, low-expansive), viscosity (viscous, low-viscous), absorbency due to the existing state and type of substrate. 


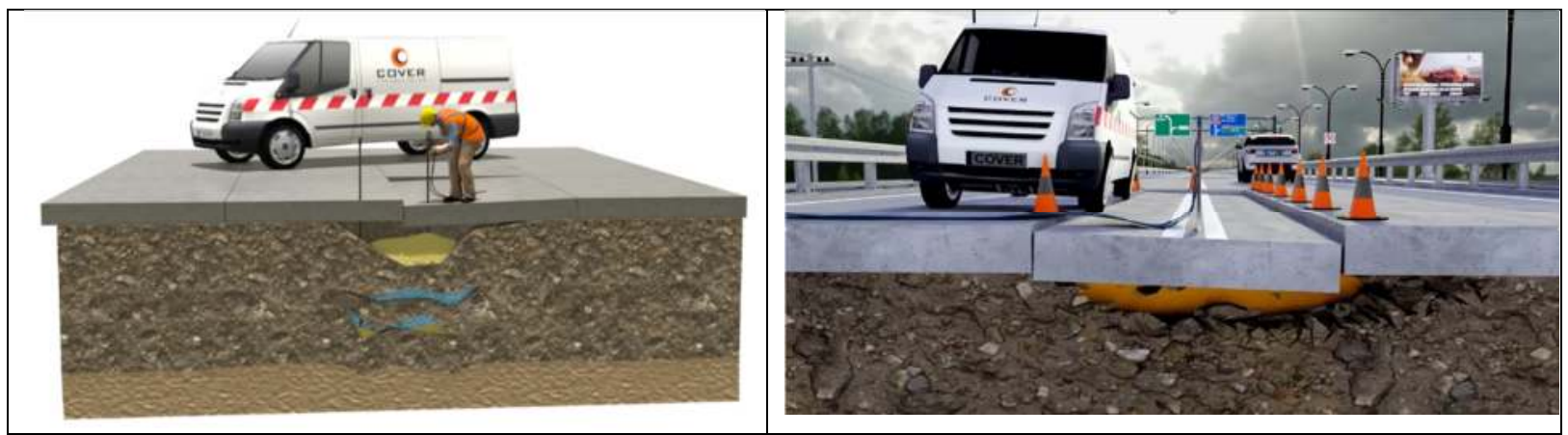

2. The use of geotechnical injection to lift the slab in the concrete pavement

\section{Geotechnical injection materials}

The materials used in strengthening injections are two-component isocyanate-silicate systems, obtained by mixing component A and component B in a 1:1 volume ratio [9]. Such materials are used in road construction to inject and lift concrete road components, fill smaller voids, and stabilize and consolidate loose rock and sand. In addition, they are used to strengthen and seal brittle and weak layers of the rock mass and coal with various degrees of moisture, prone to detachment from the body. They are also used to seal water and gas leaks.

Characteristic features of the above-mentioned materials include:

- high mechanical strength,

- achieving the desired strength in a short time,

- insensitivity to water,

- low curing temperature,

- good hydro and gas insulating properties,

- antistatic properties,

- flame retardant.

\section{The course of works related to the injection under the concrete slab}

- securing works;

- marking out the grid of pass-through holes every $1-1.5 \mathrm{~m}$, at the edges of the boards every 0.5 - $1 \mathrm{~m}$;

- drilling of perpendicular injection holes with a diameter of $14-16 \mathrm{~mm}$ across the boards in the above-mentioned grid;

- embedding steel injection lances in the above-mentioned openings;

- low-pressure injection (up to 20 bar) with fast, structural resin;

- removal of lances and sealing of openings;

- cleaning works;

- preparation of a report on the course of injection works.

\section{The process of injection}

The injection is carried out through the current lance until the further flow is blocked (sudden pressure increase and pump stop), "fresh" resin appears in the adjacent injection port or the maximum pressure is reached [9]. The recommended injection direction is a systematic injection in one direction. In the case of the injection that strengthens the injection process, we start the injection process on one side and proceed in the opposite direction. For this purpose, the respective injection lance is provided with a closing valve. An injection is carried out through this lance until the filling material exits through the next lance, there is a sharp increase in pressure or the continuity of the soil is interrupted. Here, the injection process begins again, until the above-mentioned effect is obtained on the next lance. In some places, it 
may be necessary to make a customized grid for the arrangement of the lances to avoid obstacles or no access. The injection should be continued after the shortest possible break. Running out of filler material can be refilled with the lowest possible feed pressure. A break in the injection carries the risk of insufficient filling of the structure of the injected medium. If a break is necessary, continue with the injection in the next pack after the resin has hardened.

The maximum injection pressure should not exceed 20 bar. On the other hand, it is unacceptable to burst the soil with a vein of material and uncontrolled injection of the injection into the soil environment. On the pump, the injection pressure can be read directly on the pressure gauge. Higher pressures can lead to sedimentation of the material, delamination of the soil, or damage to the structure. The technical condition of a given component may also require a restriction of the injection pressure.

\section{An example of the application of geotechnical injection technology based on resins (polymers) on the airport pavement}

The low-pressure injection technology was used to align the concrete slab on the aircraft parking space at one of the airport facilities in Poland.

Initially, tests of the elasticity modulus of two materials used in the low-pressure injection technology were carried out under laboratory conditions at the Airport Department of the Air Force Institute of Technology in order to select one of them for use in field studies. The test specimens were made of two-component materials: Cover Geolift $2 \mathrm{~K}$ and Cover Geopur 2K, used in the filling and pushing injection technology. The stabilized incisal modulus of elasticity was determined by method B according to PN-EN 12390-13: 2014-02 [11], empirically modified (Figure 3).

a)

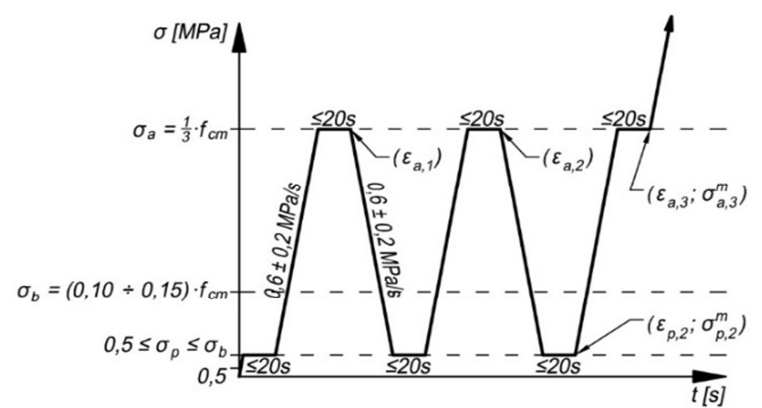

b)

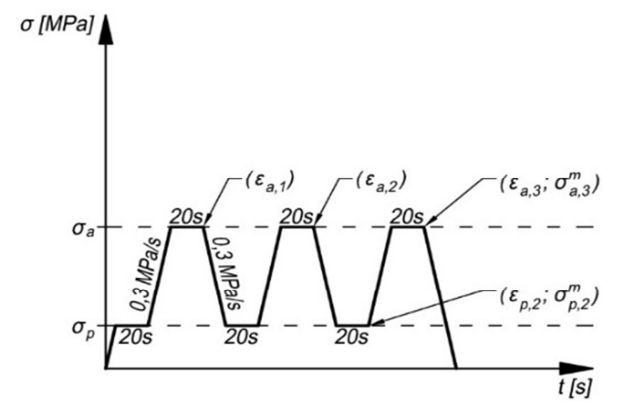

3. The test diagram of the modulus of elasticity: a) according to PN-EN12390-13: 2014-02, method B; b) modified method

The tests were performed with the use of a testing machine for static tests, type 50C9842 by Controls, and 3 deformation sensors type 55-C0222 / G by Controls with a set measuring base $\mathrm{L} 0=120 \mathrm{~mm}$ and a measuring range of $118.5 \div 121.5 \mathrm{~mm}$ (Figure 4). 


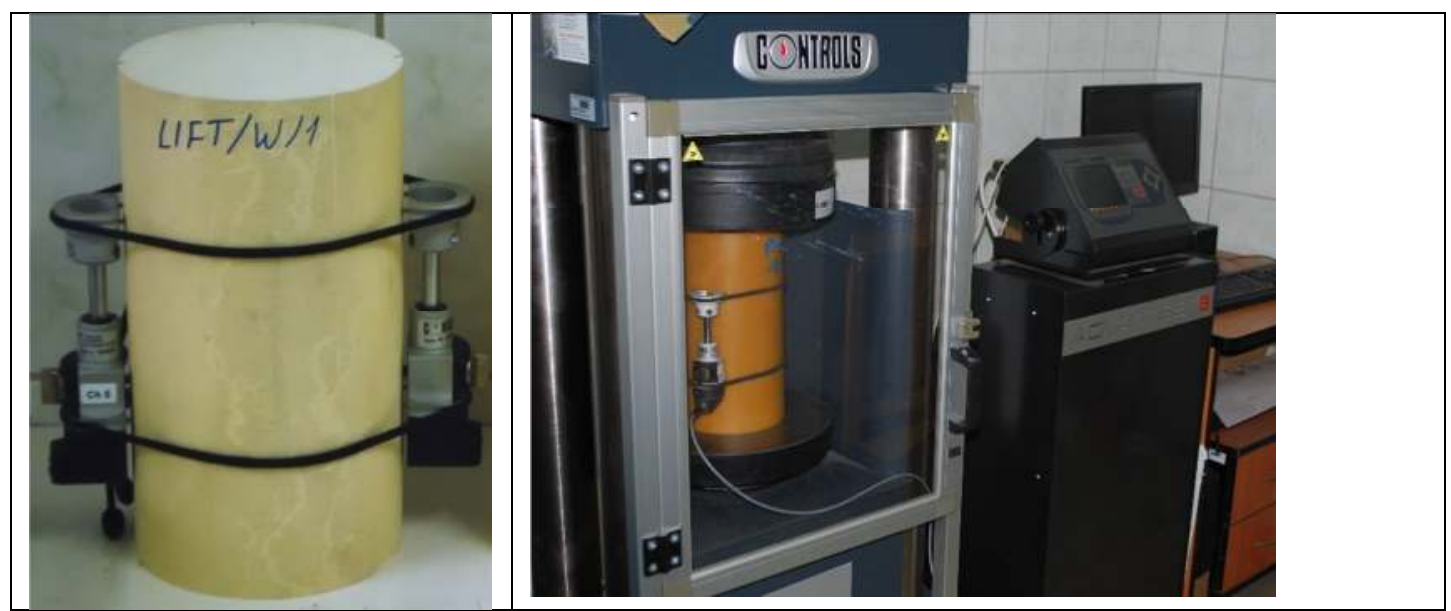

4. Testing the modulus of elasticity of a sample of material for geotechnical injection, a) a sample of Cover Geolift $2 \mathrm{~K}$ material prepared for testing $\mathrm{b}$ ) a view of a sample of Cover

Geopur $2 \mathrm{~K}$ in a testing machine

The test results are presented in the Table 1. Finally, the Cover Geolift $2 \mathrm{~K}$ material was selected for fieldwork, for which the average value of the stabilized secant modulus of elasticity was $680 \mathrm{MPa}$.

Tab. 1. Summary of the results of studies of the stabilized incisal modulus of elasticity in compression of Cover Geolift 2K and Cover Geopur 2K

\begin{tabular}{|c|c|c|c|c|c|c|c|c|c|c|}
\hline \multirow{3}{*}{$\begin{array}{l}\text { Sampl } \\
\text { e No. }\end{array}$} & \multicolumn{5}{|c|}{ Cover Geolift 2K } & \multicolumn{5}{|c|}{ Cover Geopur 2K } \\
\hline & d & $\varepsilon_{p, 2}$ & $\varepsilon_{a, 3}$ & $\Delta \varepsilon_{S}$ & $\mathbf{E}_{\mathbf{C}, \mathbf{S}}$ & d & $\varepsilon_{p, 2}$ & $\varepsilon_{\mathrm{a}, 3}$ & $\Delta \varepsilon_{S}$ & $\mathbf{E}_{\mathbf{C}, \mathbf{S}}$ \\
\hline & {$[\mathrm{mm}]$} & {$\left[10^{-6}\right]$} & {$\left[10^{-6}\right]$} & {$\left[10^{-6}\right]$} & [MPa] & {$[\mathrm{mm}]$} & {$\left[10^{-6}\right]$} & {$\left[10^{-6}\right]$} & {$\left[10^{-6}\right]$} & [MPa] \\
\hline 1 & 155,0 & 389,1 & 4516,5 & 4127,4 & 680 & 153,0 & 472,9 & 4705,1 & 4232,2 & 1540 \\
\hline 2 & 155,0 & 326,8 & 4517,0 & 4190,2 & 670 & 153,0 & 847,7 & 4722,1 & 3874,4 & 1680 \\
\hline 3 & 155,0 & 571,1 & 4661,5 & 4090,4 & 680 & 153,0 & 881,1 & 4924,8 & 4043,7 & 1610 \\
\hline & \multicolumn{4}{|c|}{ Average value } & 680 & \multicolumn{4}{|c|}{ Average value } & 1610 \\
\hline
\end{tabular}

The view of the pendulous plates is shown in Figure 5. After the tested pavement was cleaned with an airfield cleaner, injection holes were drilled (Figure 6) in accordance with the marked grid, in which steel injection lances were embedded (Figure 7), and then low-pressure injections were carried out, controlling during construction displacement works (Figure 8). 


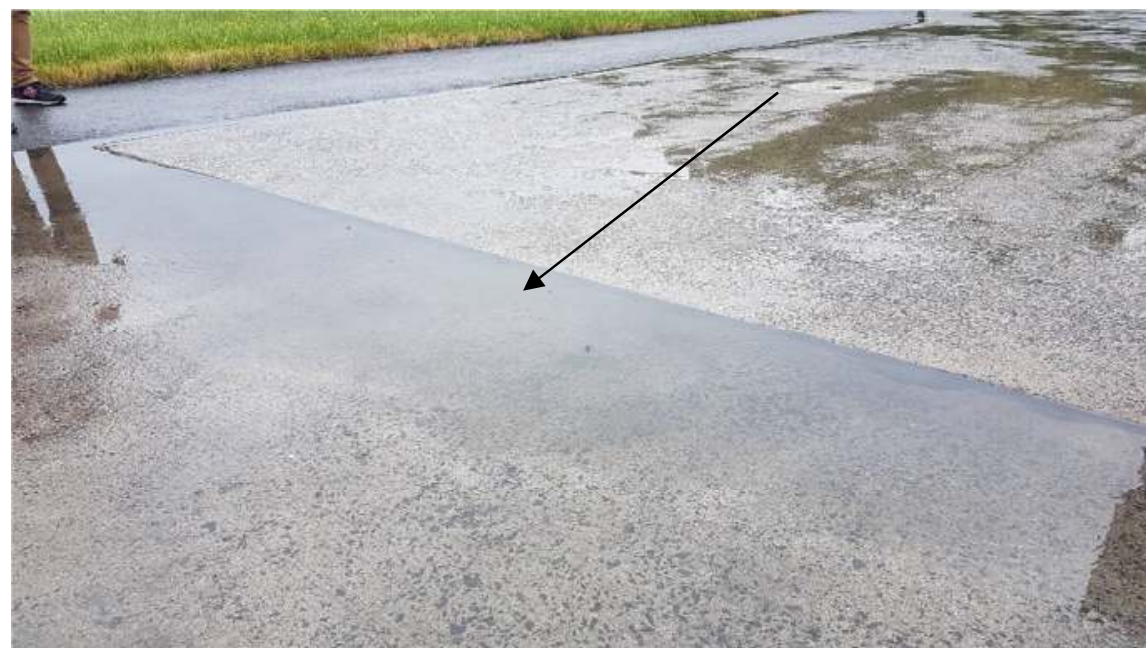

5. View of the plate edge lowering at the parking stand (flooded with water) - slot marked no. 2

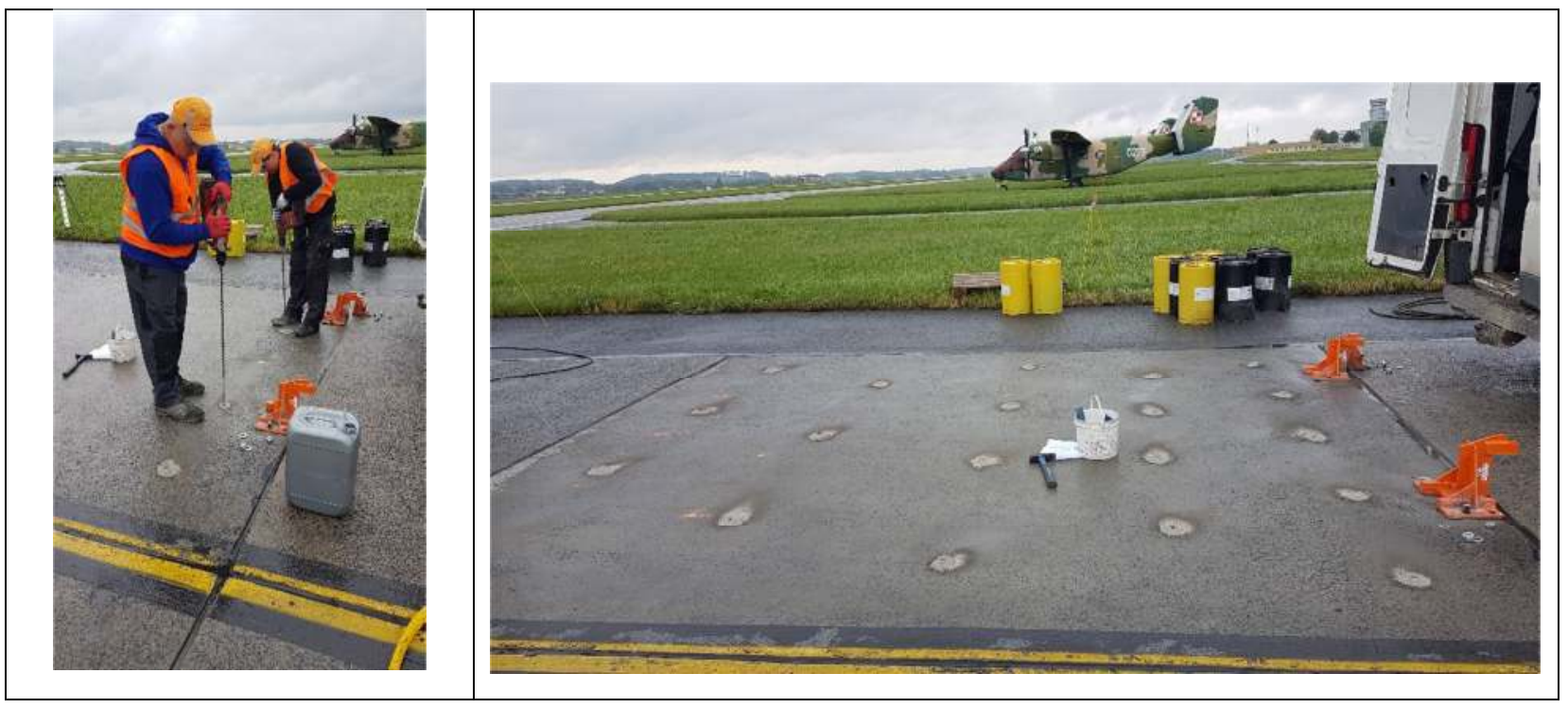

6. Drilling injection holes with a diameter of 14-16 $\mathrm{mm}$ (according to the marked grid)

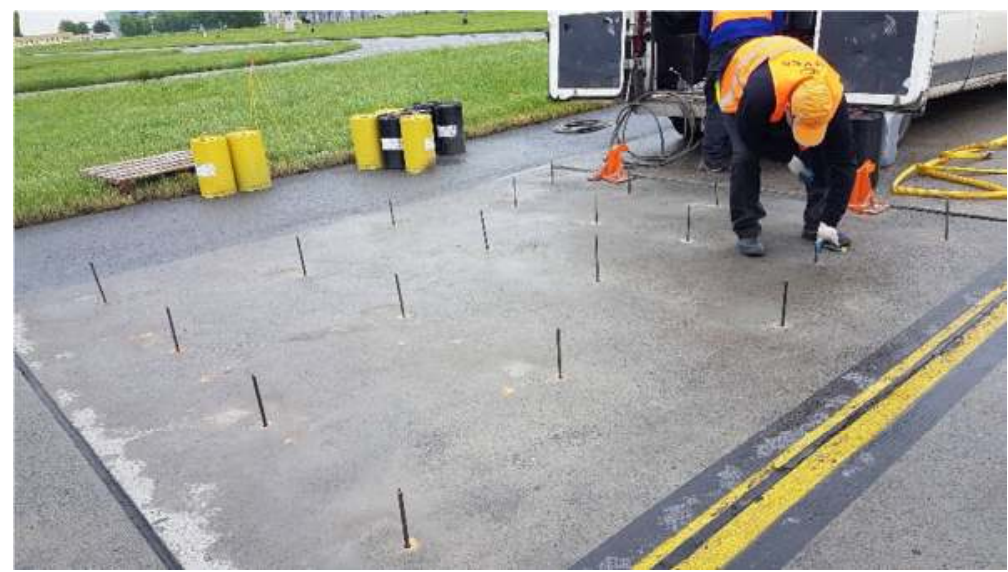

7. Embedding in drilled holes, steel injection lances 


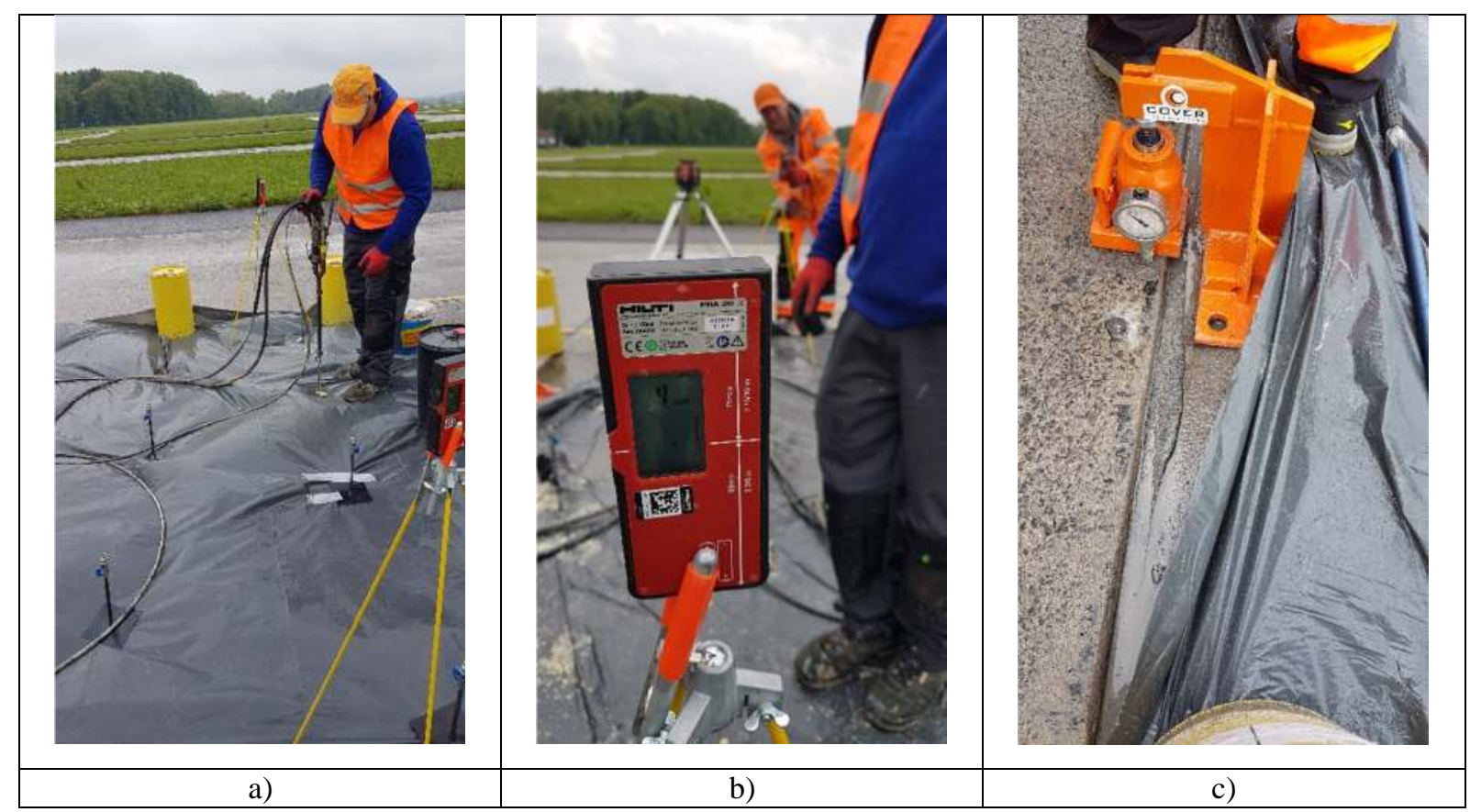

8. Performing a low-pressure injection of the foil-protected plate (a). Controlling displacements of structures during injection works $(b, c)$

Before the commencement of works and after the injection, the load-bearing capacity (cooperation of concrete slabs), evenness, and GPR tests were carried out. The structural system consisted of the following layers: surface concrete $20 \mathrm{~cm}$ thick, slip layer (tar paper), and subsoil (medium sand).

The GPR research was performed using the RIS MF HI-MOD \# 1 GPR system from the Italian company IDS, equipped with a dual-frequency antenna with a range of 600-2000 $\mathrm{MHz}$. During the measurements, due to the presence of moisture on the surface of the element and locally occurring puddles, the depth range of the GPR was about $1.0 \mathrm{~m}$ below sea level. Figure 9 shows a characteristic profile for the analyzed area before injection, and Figure 10 - a characteristic profile after injection.

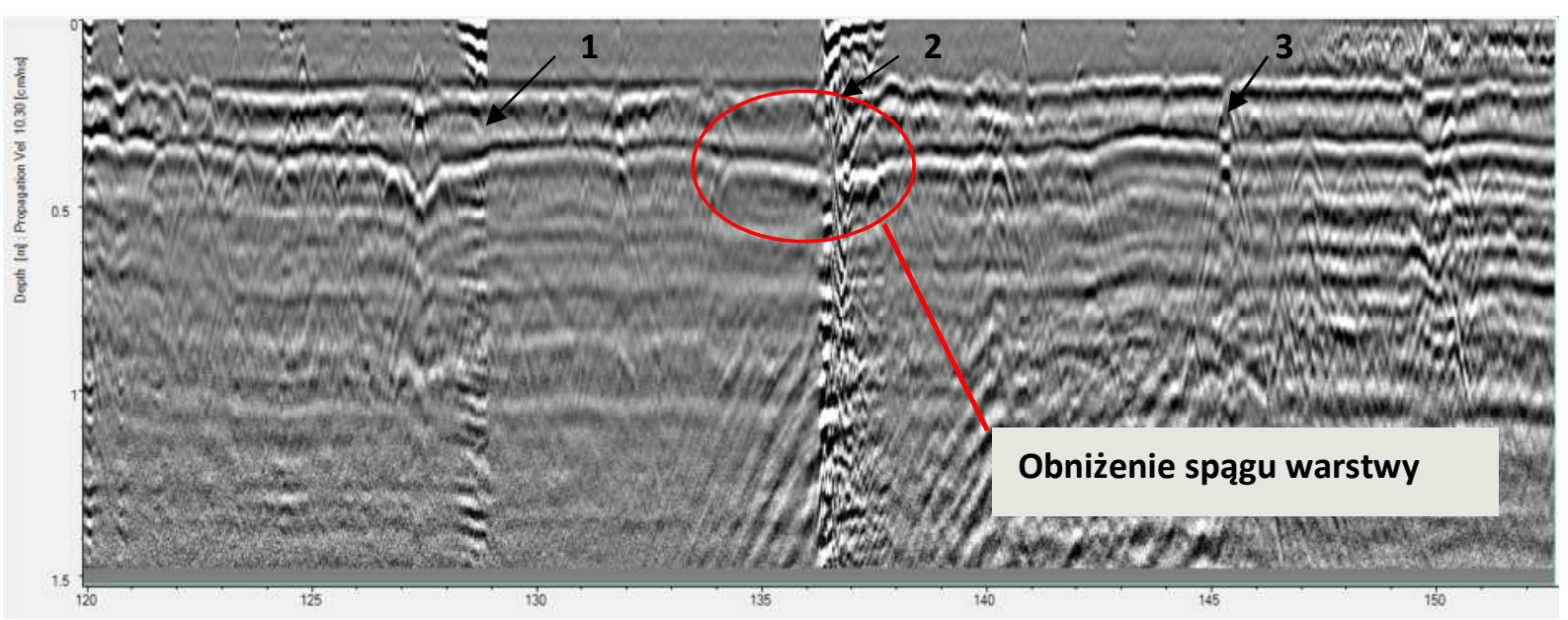

9. Echogram showing the longitudinal profile (including 4 plates) obtained as a result of GPR measurement before injection. Expansion gaps are marked with numbers 


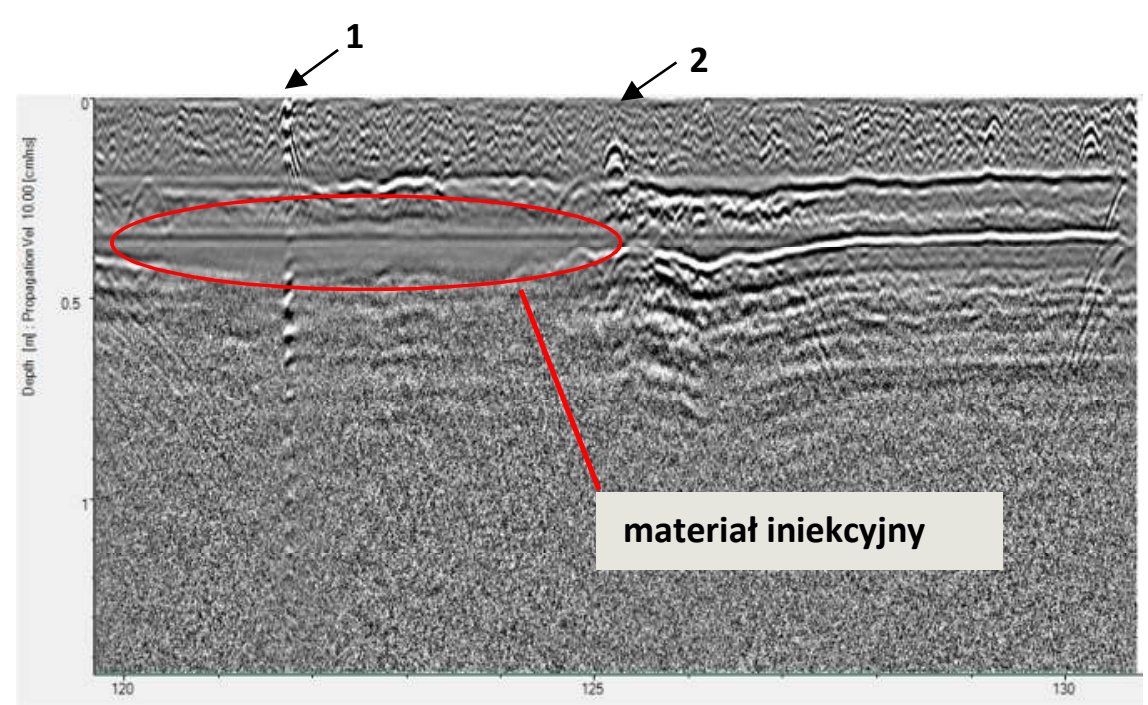

10. Echogram showing the longitudinal profile obtained as a result of the measurement after the injection

The visible expansion gaps between the boards are marked with numbers on the individual profiles. The existing undercutting of the floor of the layer located directly under the structure of the lifted slab allows us to believe that there has been a reduction in the degree of soil compaction in this area, compared to the ground in the immediate vicinity. Most likely, this phenomenon resulted in the displacement of the concrete slab. GPR tests performed after the injection procedure showed changes in the subsoil located directly under the slab structure. The echograms showed an area showing different characteristics compared to the subsoil. In connection with the performed procedures, it should be assumed that this is the injected material. Much of the material was introduced under the plate immediately adjacent to the lift plate.

Measurements of unevenness were made with a $3 \mathrm{~m}$ long patch. The surface evenness was assessed on the basis of the defectiveness criterion, in accordance with NO-17-A502: 2015 and NO-17-A204: 2015 [12, 14]. Measurements were carried out in randomly selected places where there were no obstacles that could affect the value of the measured inequalities. As a result of the research, it was found that the equality after the injection improved by $3.7 \%$ compared to the results obtained before the injection.

The cooperation of adjacent concrete slabs embedded in the pavement of the studied area was tested with the use of a Heavy Weight Deflectometer (HWD). Figure 11 shows the HWD impact deflection meter during the measurements of elastic deflections of the pavement of the tested section at the connection of concrete slabs.
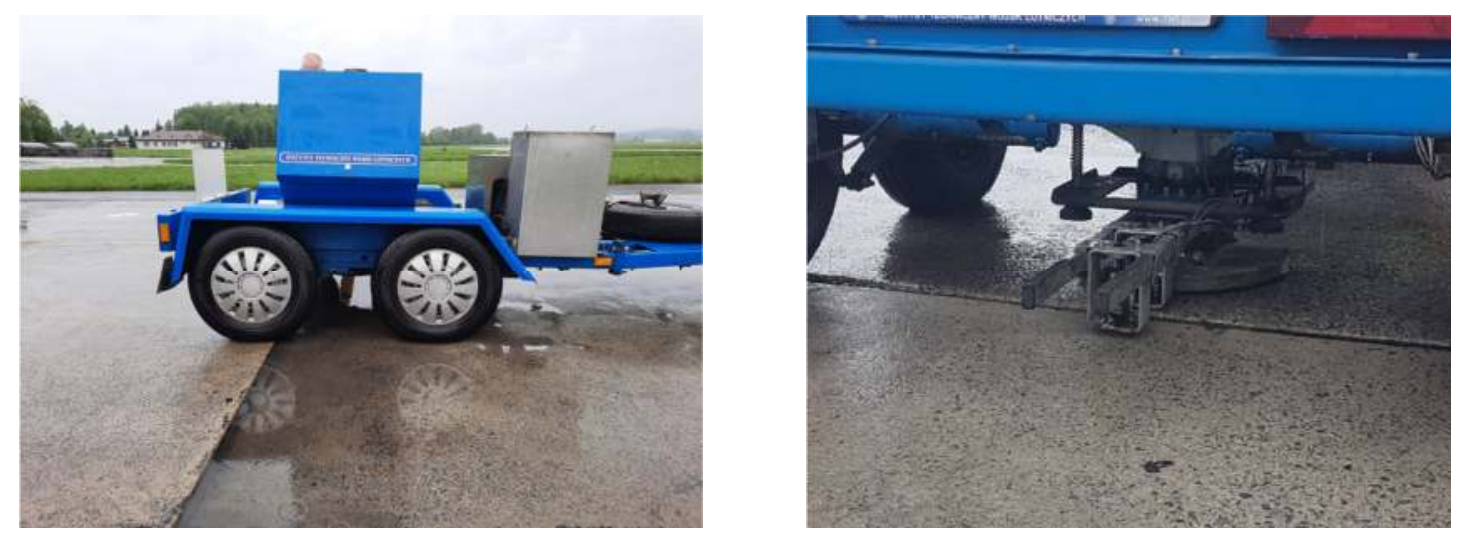

11. HWD impact deflector during measurements of elastic deflections 
The test was carried out by measuring the elastic deflections at the edges of adjacent concrete slabs of the assessed airport pavement with a plate with a diameter of $450 \mathrm{~mm}$, with a force transmitted to the pavement of about $200 \mathrm{kN}$. The results of testing the cooperation of concrete slabs before and after the injection are presented in the Table $\mathbf{2}$.

Tab. 2.Results of testing the cooperation of concrete slabs before injection (baseline) and after injection

\begin{tabular}{|c|c|c|c|c|c|}
\hline $\begin{array}{c}\text { Measurement } \\
\text { point }\end{array}$ & $\begin{array}{c}\text { Tension under } \\
\text { the slab }\end{array}$ & Drop force & $\begin{array}{c}\text { Sensor 2 } \\
\text { deflection }\end{array}$ & $\begin{array}{c}\text { Sensor 3 } \\
\text { deflection }\end{array}$ & J \\
\hline \hline \multicolumn{7}{|c|}{ Research before injection } \\
\hline \hline 1 & {$[\mathrm{kPa}]$} & {$[\mathrm{kN}]$} & {$[\mu \mathrm{m}]$} & {$[\mu \mathrm{m}]$} & {$[\%]$} \\
\hline \hline 2 & 1277,00 & 203,02 & 1580,20 & 967,80 & $\mathbf{6 1 , 2}$ \\
\hline 3 & 1233,00 & 196,07 & 1051,00 & 694,20 & $\mathbf{6 6 , 1}$ \\
\hline 4 & 1253,00 & 199,28 & 2009,30 & 1387,50 & $\mathbf{6 9 , 1}$ \\
\hline 5 & 1226,00 & 194,95 & 1177,10 & 766,30 & $\mathbf{6 5 , 1}$ \\
\hline 6 & 1243,00 & 197,66 & 1355,50 & 864,20 & $\mathbf{6 3 , 8}$ \\
\hline \hline \multicolumn{7}{|c|}{ Average value: } \\
\hline \hline \multicolumn{7}{|c|}{ Post-injection studies } & $\mathbf{7 1 , 3}$ \\
\hline \hline 1 & 1232,00 & 195,91 & 1132,70 & 808,10 & $\mathbf{6 6 , 1}$ \\
\hline 2 & 1224,00 & 198,88 & 977,90 & 727,90 & $\mathbf{7 4 , 4}$ \\
\hline 3 & 1217,00 & 194,59 & 798,10 & 726,10 & $\mathbf{9 1 , 0}$ \\
\hline 4 & 1235,00 & 196,34 & 1089,60 & 858,70 & $\mathbf{7 8 , 8}$ \\
\hline 5 & 1245,00 & 198,01 & 879,10 & 736,60 & $\mathbf{8 3 , 8}$ \\
\hline 6 & 1248,00 & 198,45 & 751,10 & 705,00 & $\mathbf{9 3 , 9}$ \\
\hline \hline \multicolumn{7}{|c|}{ Average value: } \\
\hline
\end{tabular}

During the tests, elastic deflections in the center of the concrete slab were also measured before the injection (reference state) and after the procedure, in accordance with the standards NO-17-A500: 2016 and NO-17-A204: 2015 [13, 14]. Then, as a result of the analysis, the values of the measured elastic deflections and the values of the equivalent modules of the structure were compared (Table 3 ).

Tab. 3: Results of elastic deflection measurements

\begin{tabular}{|c|c|c|c|c||}
\hline $\begin{array}{c}\text { The condition of the pavement during } \\
\text { the measurement }\end{array}$ & $\begin{array}{c}\text { Tension } \\
\text { under the } \\
\text { slab }\end{array}$ & Drop force & Deflection & $\begin{array}{c}\text { Replacement } \\
\text { module }\end{array}$ \\
\hline \hline Before the injection (baseline) & 1229,00 & 195,51 & $\mathbf{8 0 0 , 8 0}$ & $\mathbf{6 9 0 , 6}$ \\
\hline After injection & 1231,00 & 195,83 & $\mathbf{1 0 7 5 , 4 0}$ & $\mathbf{5 1 5 , 1}$ \\
\hline
\end{tabular}


On the basis of the obtained test results, it can be concluded that the cooperation between the boards before injection was limited and the average value of the load transfer coefficient was $66.1 \%$. After the injection, the average value of the load transfer coefficient was $83.4 \%$, which means good cooperation of the plates. Considering the above, it should be stated that the tested technology improves the cooperation of the plates when transferring the load. The results of the elastic deflection measurements show that the performed injection contributed to the increase of elastic deflections of the pavement $(1075.4 \mu \mathrm{m})$ by $34.3 \%$ compared to the state before the procedure $(800.8 \mu \mathrm{m})$. The average value of the calculated equivalent modulus of the pavement structure after injection (515.1 MPa) decreased by $25.4 \%$ compared to the reference state $(690.6 \mathrm{MPa})$.

\section{Summary}

Due to the destructive processes taking place in concrete and the resulting damage to concrete, it is important to perform periodic inspections of the technical condition of the pavement, which allow for monitoring of the changes taking place and at the same time planning maintenance works consisting in performing repairs and protective treatments. In the case of airports, all kinds of damage to the plates pose a threat to the safety of moving aircraft. The technology of low-pressure injection with the use of fast-acting injection resins (geopolymers) allows for leveling the slabs in the concrete pavement without the need to demolish the object (disassembly of the slabs) while restoring the required parameters of the pavement in terms of evenness. As a result of the injection, there is also a thickening, consolidation of loosened soil masses, filling empty spaces, filling aquifers.

At airports in Poland, there is no experience in the use of geotechnical injection technology to remove thresholds between the edges of adjacent concrete slabs. For this reason, the performed experimental section will be the subject of observation and further research on changes in structural parameters over time.

\section{Source materials}

[1] Poteraj-Oleksiak A.: Wzmacnianie podłoża gruntowego i podbudowy dróg betonowych przy pomocy iniekcji geopolimerowych. II Suwalskie Forum Drogowe, Suwałki, 16.03.2018 r.

[2] Wesołowski M., Pietruszewski P, Poświata A., Kowalska D. Ocena równości nawierzchni lotniskowych $\mathrm{w}$ aspekcie obowiązujących dokumentów normatywnych. Przegląd komunikacyjny, 2018, R. 73 nr 12, 24-29.

[3] Wesołowski M., Blacha K., Rumak A. Influence of the load bearing capacity a concrete airfield pavement constructions on the safety of air operations. Proceedings of the 29th European Safety and Reliability Conference, 2019, nr DOI: 10.3850/978-981-11-27243-0500-cd.

[4] Wesołowski M., Iwanowski P.: APCI Evaluation Method for Cement Concrete Airport Pavements in the Scope of Air Operation Safety and Air Transport Participants Life, Int. J. Environ. Res. Public Health, 17(5), 1663, 2020.

[5] P. Nita: Budowa i utrzymanie nawierzchni lotniskowych. Wydawnictwa Komunikacji i Łączności WKŁ, 2008.

[6] M. Y. Shahin: Pavement Management for Airports, Roads and Parking Lots. Spinger, 2006.

[7] A. Szydło: Nawierzchnie drogowe z betonu cementowego. Polski Cement, 2004.

[8] M. Wesołowski: Kompleksowa ocena stanu technicznego nawierzchni elementów funkcjonalnych lotnisk w aspekcie bezpieczeństwa lotów. Wydawnictwo Instytutu Technicznego Wojsk Lotniczych, 2020.

[9] www.covertechnologies.com, 23.09.2021. 
[10] Norma PN-EN 12715:2021-05 Wykonawstwo specjalistycznych robót geotechnicznych. Iniekcja

[11] Norma PN-EN 12390-13:2014-02 Badania betonu. Część 13. Wyznaczanie siecznego modułu sprężystości przy ściskaniu.

[12] Norma obronna NO-17-A502:2015 Nawierzchnie lotniskowe. Badanie równości.

[13] Norma obronna NO-17-A500:2016 Nawierzchnie lotniskowe i drogowe. Badanie nośności.

[14] Norma obronna NO-17-A204:2015 Nawierzchnie lotniskowe. Nawierzchnie z betonu cementowego. Wymagania i metody badań. 